\title{
The Outbreak of Covid-19 as an Overmacht Claim in Credit Agreements
}

\author{
Merry Tjoanda $^{1}$, Yosia Hetharie ${ }^{2}$, Marselo V.G Pariela ${ }^{3}$, \\ Ronald F. Sopamena ${ }^{4}$
}

\footnotetext{
${ }^{1}$ Faculty of Law, Universitas Pattimura, Indonesia, E-mail: merry.tjoanda@gmail.com

${ }^{2}$ Faculty of Law, Universitas Pattimura, Indonesia, E-mail: josephushetharie@gmail.com

${ }^{3}$ Faculty of Law, Universitas Pattimura, Indonesia, E-mail: mpariela@ gmail.com

${ }^{4}$ Faculty of Law, Universitas Pattimura, Indonesia, E-mail: rfsopamena@gmail.com
}

Submitted: December 16, 2020; Reviewed: January 18, 2021; Accepted: January 20, 2021

\begin{tabular}{ll}
\hline \multicolumn{1}{c}{ Article Info } & \multicolumn{1}{c}{ Abstract } \\
\hline Keywords: & This research aims to determine and analyze the law \\
Overmacht, Credit Agreement, & consequences of overmacht in credit agreements due \\
Covid-19 & to the Covid-19 Pandemic and as legal remedies for \\
Dottlement of the credit agreement due to the Covid- & 19 Pandemic. This research is socio-legal research, \\
10.25041/fiatjustisia.v15no1.2195 & a combination research method between doctrinal \\
& law research methods and empirical legal research \\
methods. This research was conducted in banking & institutions and financing institutions in Ambon City, \\
namely at Bank Mandiri Ambon Branch Office, BCA \\
Ambon Branch Office, Bank Artha Graha Ambon \\
Branch Office, and BFI Limited Company Ambon \\
Branch Office. The types of research data are \\
primary data and secondary data, obtained through \\
literature study and interviews. Based on the results \\
of the research, the Covid-19 Pandemic is a non- \\
natural disaster, so it is categorized as a relative \\
overmacht, so the result of the comparative \\
overmacht law in the credit agreement due to the \\
Covid-19 Pandemic in Ambon City has not changed \\
the risk burden in the sense that the Debtor still \\
fulfills their achievements after the outbreak of \\
Covid - 19 Pandemic is over. The legal effort that \\
can be taken to settle credit agreements due to \\
Covid-19 Pandemic in Ambon City is through credit \\
restructuring in the form of lowering interest rates, \\
extending the period, reducing principal arrears, \\
and reducing interest arrears as determined by the \\
government to be implemented by the bank or \\
financing institutions with debtors.
\end{tabular}




\section{A. Introduction}

As God's most perfect creature, humans are social creatures who cannot live alone because they need other humans or other living creatures to fulfill their needs. Among other humans, interaction and reciprocal relations are always created in social relation or legal relation. Every legal relation created by law always has two aspects, the rights, and the obligations. ${ }^{1}$ The legal relationship created between one human with another, for example, is an agreement. The agreement is an essential instrument in business activities. ${ }^{2}$ This legal relation in the form of an agreement creates rights and obligations that must be carried out by the parties that made it. The agreement made by the parties is also a law for the concrete relation. ${ }^{3}$. The agreement is defined as "a legal relationship between two or more parties based on an agreement with legal consequences. ${ }^{4}$

Contracts based on consensus are not purely the contract product in the eighteenth and nineteenth centuries because long before Roman law recognized consensus contracts. ${ }^{5}$ The progress of legal agreement began in Roman times with the background that a vow uttered by someone was considered a promise not only to humans but also to God. The breach of this vow was a violation of Roman religious teachings. ${ }^{6}$ The priests of Roman were given the authority to punish those who commit violations because vow is religious teachings. ${ }^{7}$

The principles used in the agreement are generally influenced by the civil law system and the standard law system. ${ }^{8}$ Indonesian legal agreement currently adheres to the civil law tradition, guided by rules inherited from the colonial government of the Dutch East Indies. Another fact that appears is the Dutch influence, which has embedded the pillars of provisions that bind

\footnotetext{
${ }^{1}$ Ari Hernawan, "Keseimbangan Hak dan Kewajiban Pekerja dan Pengusaha Dalam Mogok Kerja," Mimbar Hukum 24, no. 3 (2012): 418-30, 419, DOI: 10.22146/jmh.16119.

${ }^{2}$ Hanifah Nuraini, Dauri, And Ricco Andreas, "Paradigma Interpretif Konsep Penyalahgunaan Keadaan (Misbruik Van Omstandigheden) Pada Perjanjian Kredit Perbankan," Refleksi Hukum: Jurnal Ilmu Hukum 4, no. 2 (2020): 259-80, 260, DOI: 10.24246/jrh.2020.v4.i2.p259-280.

${ }^{3}$ Yosia Hetharie, "Perjanjian Nominee Sebagai Sarana Penguasaan Hak Milik Atas Tanah Oleh Warga Negara Asing (WNA) Menurut Kitab Undang-Undang Hukum Perdata," SASI 25, no. 1 (2019): 27-36, 30, DOI: 10.47268/sasi.v25i1.147.

${ }^{4}$ Yosia Hetharie, "Default in Sea Transportation Agreement," Law Research Review Quarterly 6, no. 2 (2020): 181-184, 181, DOI: 10.15294/lrrq.v6i2.37900.

${ }^{5}$ Ridwan Khairandy, "Landasan Filosofis Kekuatan Mengikatnya Kontrak," Jurnal Hukum IUS QUIA IUSTUM 18, (2011): 36-55, 44.

${ }^{6}$ Agri Chairunisa Isradjuningtias, "Force Majeure (Overmacht) Dalam Hukum Kontrak (Perjanjian) Indonesia," Veritas et Justitia 1, no. 1 (2015): 136-158, 136, DOI: 10.25123/vej.1420.

${ }^{7}$ C. F. G. Sunaryati Hartono, Examining the Form and System of Our National Treaty Law (Bandung: Alumni, 1969), 13.

${ }^{8}$ D. R. (Dwi) Hapsari, "Kontrak Dalam Kitab Undang - Undang Hukum Perdata Dan Hukum Islam (Suatu Kajian Dalam Perspektif Asas - Asas Hukum)," Repertorium 1, no. 1 (2014): 8394, 83.
} 
society and the authorities and society and society itself. ${ }^{9}$ Another evidence of the relationship between Dutch law and Indonesia is civil law or BurgerlijkWetboek $(B W) .{ }^{10}$ The Civil Code provides explicit arrangements regarding interpreting contracts/agreements in Book Three, Chapter Two, Part Four, starting from the provisions of Article 1342 to Article 1351. ${ }^{11}$

Subekti defines the connection between the obligation and agreement first by providing definitions to the two terms. An agreement is an event where someone promises another person or where the two people promise each other to do something. From that event, a connection arises between the two people, which is called an obligation. An obligation (verbintenissen) is a connection between two people or two parties. One party has the right to demand something from the other party, and the other party is obliged to fulfill that demand. The connection between the obligation and the agreement, namely that the agreement gives rise to an obligation, another source is the law. An obligation is an abstract meaning, while an agreement is a tangible thing on an event. ${ }^{12}$

Agreements or contracts are currently developing rapidly as a logical consequence of business cooperation development between business people. ${ }^{13}$ Sudikno Mertokusumo proposed 3 (three) principles of agreement law, namely the principle of consensual, an agreement of will (related to the legitimacy of an agreement), the principle of the strength of binding an agreement (related to the consequences of the agreement) and the principle of freedom of contract (related to the contents of the agreement). ${ }^{14}$

In the enforcement of the agreement, the principle of pacta sunt servanda is often challenging to implement if there is a change in fundamental circumstances. The conditions on which the agreement is made have changed, and the change affects the promised parties' ability. It is not uncommon for changes in circumstances such as price increases, changes in currency exchange rates, and war conditions can cause one or more parties to the agreement to suffer losses if the agreement is executed. Several disputes in the agreement, including changes in circumstances, but the Code of Civil Law as the central provision in the agreement law have not accommodated this. And

\footnotetext{
${ }^{9}$ Rene David and John. E. C. Brierley, Major Legal Systems in the World Today (London: Stevens \& Sons, 1978), 21.

${ }^{10}$ Taryana Sunandar, Unidroit Principles as a Source of Contract Law and Dispute Resolution (Jakarta: Sinar Grafika, 2004), 3.

${ }^{11}$ Bambang Sutiyoso, "Penafsiran Kontrak Menurut Kitab Undang-Undang Hukum Perdata Dan Maknanya Bagi Para Pihak Yang Bersangkutan," Jurnal Hukum Ius Quia Iustum 20, no. 2 (2013): 207-233, 208, DOI: 10.20885/iustum.vol20.iss2.art3.

${ }^{12}$ Henry Pandapotan Panggabean, The Supreme Court's Role through the Bond of Obligation Law Decisions (Bandung: Alumni, 2008), 71.

13 Muhammad Noor, "Penerapan Prinsip-Prinsip Hukum Perikatan Dalam Pembuatan Kontrak," Mazahib 14, no. 1 (2015): 89-96, 89.

${ }^{14}$ Henry Pandapotan Panggabean, Loc.Cit.
} 
this is often related to circumstances that are beyond estimates (force majeure) or also known as an overmacht. ${ }^{15}$

The definition of anovermacht in the Code of Civil Law states that an overmacht is "a situation in which a debtor is prevented from giving something or doing something or doing an act prohibited in the agreement". ${ }^{16}$ The term used to describe force majeure / overmacht is a forced state. ${ }^{17} \mathrm{~A}$ forced state is defined as "an event beyond the control of one party". Which effect delays or causes the performance of a party's obligations under the agreement is impossible, and once it arises, the party cannot avoid or resolve the incident. ${ }^{18}$

Based on Article 1338 of the Code of Civil Law, every agreement must obey the principle of good faith (bonafide) in its enforcement because of its binding character, like a law. ${ }^{19}$ Exceptions from this provision are found in the provisions governing the overmacht, namely in Article 1244 and Article 1245 of the Code of Civil Law. ${ }^{20}$ The legal system of the Code of Civil Law does not introduce the principle of rebus sic stantibus in the realm of contract law but instead puts forward the aspect of overmacht.

In December 2019, cases of mysterious pneumonia were first reported in Wuhan, Hubei Province. The source of the transmission of this case is still uncertain, but the first case was linked to a fish market in Wuhan. ${ }^{21}$ From 18 December to 29 December 2019, five patients were treated with Acute Respiratory Distress Syndrome (ARDS). ${ }^{22}$

Researchers of Fornano\& Wolf (Corona and Macroeconomic Policy, 2020) stated that "the coronavirus outbreak will cause a negative supply shock to the world economy, by forcing factories to shut down and disrupting global supply chains". The Institute for Development of Economics and Finance (INDEF) then abstracted the research results of Fornano\& Wolf's in more

\footnotetext{
15 Wardatul Fitri, "Implikasi Yuridis Penetapan Status Bencana Nasional Pandemi Corona Virus Disease 2019 (COVID-19) Terhadap Perbuatan Hukum Keperdataan," Supremasi Hukum: Jurnal Kajian Ilmu Hukum 9, no. 1 (2020): 76-93, 82.

${ }^{16}$ Henry Pandapotan Panggabean, Loc.Cit.

${ }^{17}$ Daryl John Rasuh, "Kajian Hukum Keadaan Memaksa (Force Majeure) Menurut Pasal 1244 Dan Pasal 1245 Kitab Undang-Undang Hukum Perdata," Lex Privatum 4, no. 2 (2016): 173$180,174$.

18 Lathifah Hanim and MS. Noorman, "Penyelesaian Perjanjian Kredit Bank Sebagai Akibatforce Majeure Karena Gempa Di Yogyakarta," Jurnal Pembaharuan Hukum 3, no. 2 (2016): 161-171, 162, DOI: 10.26532/jph.v3i2.1406.

${ }^{19}$ Manaon Damianus Sirait, Johannes Ibrahim Kosasih, and Desak Gede Dwi Arini, "Asas Itikad Baik Dalam Perjanjian Sewa-Menyewa Rumah Kantor," Jurnal Analogi Hukum 2, no. 2 (2020): 221-227, 223, DOI: 10.22225/ah.2.2.1934.221-227.

${ }^{20}$ Elfiani, "Akibat Overmacht (Keadaan Memaksa) Dalam Perjanjian Timbal Balik," Al Hurriyah: Jurnal Hukum Islam 13, no. 1 (2018): 65-77, 70, DOI: 10.30983/Alhurriyah.V13I1.582.

${ }^{21}$ HA Rothan, Byrareddy SN,"The Epidemiology and Pathogenesis Of Coronavirus Disease (Covid-19) Outbreak", Journal Autoimmun 109, (2020): 102433, DOI: 10.1016/j.jaut.2020.102433

${ }^{22}$ Ibid.
} 
straightforward language that the Covid-19 Pandemicis predicted to cause supply-demand-side shocks, which include decreased production of goods, decreased income, a wave of layoffs, decreased purchasing potency, decreased demand for goods.

In this regard, the Financial Services Authority (OJK) issued the Regulation of Financial Services Authority Number 11 / POJK.03 / 2020 concerning National Economic Stimulus as a Countercyclical Policy for the Impact of the Spread of Corona Virus Disease 2019 (in the future referred to as POJK No.11 / 2020).

However, it should be noted; the restructuring/credit relief policy/financing is left to the Bank. In this case, the Bank will conduct a selfassessment with guidelines that contain the criteria for debtors and sectors affected by Covid-19. Based on the description above, we are interested in conducting legal research with the title "Overmacht in Credit Agreement due to The Covid-19 Pandemic".

As maintained with the problems and purposes of this research, the type of research is socio-legal research, ${ }^{23}$ which is a combination research method between doctrinal law research methods and empirical legal research methods. The approach used in this research is a conceptual approach and a statutory approach. This research was conducted in banking institutions and financing institutions in Ambon City, namely at Bank Mandiri Ambon Branch Office, BCA Ambon Branch Office, Bank Artha Graha Ambon Branch Office, and BFI Limited Company Ambon Branch Office. The types of research data are primary data and secondary data obtained through literature study and interviews.

\section{B. Discussion}

\section{The Influence of Covid-19 Pandemicin Credit Agreements at Banking Institutions and Financing Institutions in Ambon City}

Covid-19 is a disease which identified cause is a corona virus, which attacks the respiratory tract. ${ }^{24}$ The Covid- 19 Pandemic is a pandemic of the ongoing corona virus disease in 2019 (Covid-19), caused by the Syndrome Acute Respiratory Corona Virus 2 (SARS-CoV-2). The Covid-19 Pandemic has hit almost the entire world, including the State of Indonesia, which was only discovered in February 2020 until now, and its transmission has

\footnotetext{
${ }^{23}$ Sulistyowati Irianto, Introducing Sociolegal Studies and Its Methodological Implementation, inSulistyowaty and Sidharta (eds), Research Methods of Law of Constellation and Reflection, p. 177. See also Sulistyowati Irianto in the same book, Legal Practice: Sociolegal Perspectives (Jakarta: Obor Foundation, 2009), 308.

${ }^{24}$ Theresia Louize Pesulima and Yosia Hetharie, "Legal Protection of Work Safety for Workers Health Due to the Covid-19 Pandemic", SASI Journal 26, no. 2 (2020): 281.
} 
developed quite rapidly. ${ }^{25}$

Therefore, the government issued Presidential Decree No.12 the Year 2020 concerning the Establishment of Non-Natural Disasters due to the spread of Covid-19. ${ }^{26}$ The Covid-19 Pandemic that occurred greatly affected all aspects of human life globally, such as affecting human health and even resulting in death. In addition to its impact on human health, the Covid-19 Pandemic also affects all countries' economic systems around the world, including Indonesia.

From an economic aspect, theCovid-19 Pandemichas an effect, such as the obstruction of the production process, the scarcity of raw materials available in society to meet the needs of life, the cessation of the tourism, entertainment, and hospitality industry and aviation due to social restrictions and area closure policies, which make the businessmen make an efforts to reduce employees, and even layoffs (PHK). It makes decreased income and the increased number of unemployed due to job losses.

Apart from affecting the industrial sector stated above, the Covid-19 Pandemicalso affected the industry sector of financial services such as banking institutions and financial institutions to implement credit agreements with debtors.

According to research result in several banking and financing institutions in Ambon City, it was found that the Covid-19 Pandemic also affected credit agreements carried out by banks and debtors, such as:

a. Bank Mandiri Ambon Branch Office

Through an interview with the Manager of Customer Relationship of Consumer Loan at Bank Mandiri, Ambon Branch Office on behalf of Mr. ArfanSetiawan, as one of the government banks that also provides credit services to the public, the outbreak of Covid-19 Pandemic significantly affects the implementation of the credit agreement between Bank Mandiri and debtors in terms of accomplishment by the Debtor itself. According to him, before the outbreak of the Covid-19 Pandemic, the fulfillment of Debtor's achievements in paying installments and credit interest did not experience many obstacles or defaults. However, since the outbreak of Covid-19 Pandemic began spread to Indonesia, Bank Mandiri credit debtors were unable to pay interest and installment credit as specified in the credit agreement.

b. Bank BCA Ambon Branch Office

Just as it happened to Bank Mandiri, Bank BCA Ambon Branch Office was also affected by the Covid-19 Pandemic in terms of implementing

\footnotetext{
${ }^{25}$ Alessandro Allegra et al., "Immunopathology of SARS-CoV-2 Infection: Immune Cells and Mediators, Prognostic Factors, and Immune-Therapeutic Implications," International Journal of Molecular Sciences 4, no. 3 (2020): 194-201, 194, DOI: 10.3390/ijms21134782.

${ }^{26}$ Marhaeni Ria Siombo and Emmanuel Ariananto Waluyo Adi, "Implikasi KEPPRES No.12 Tahun 2020 Pada Perusahaan Pembiayaan," Refleksi Hukum: Jurnal Ilmu Hukum 5, no. 1 (2020): 85-104, 85, DOI: 10.24246/jrh.2020.v5.i1.p85-104.
} 
credit agreements with debtors. Some debtors affected by the Covid19 Pandemic were were unable to fulfill their achievements by paying installments and credit interest. According to the interview results with the Account Officer in BCA Ambon Branch Office, Mr. JohnyThes, according to him, if this continues and does not know when it will end, the impact will be even more significant spread to the banking sector. Many banking systems have gone out of business due to the pandemic situation, extraordinary financial market turmoil, and currency depreciation.

c. Bank Artha Graha Ambon Branch Office

From theinterview data, such as what happened to Bank Mandiri Ambon Branch Office andBank BCA Ambon Branch Office, Bank Artha Graha Indonesia, as a private bank that also provides many credit facilities for debtors, is also affected by the implementation of the credit agreement. Due to this pandemic, many borrowers are unable to fulfill their obligations to pay installments and interest before the due date. This was stated by Sherlianingsih Meronda, Legal Staff of Bank Artha Graha, Ambon Branch Office.

d. BFI Limited Company Ambon Branch Office

Based on research results at BFI Limited Company Ambon Branch Office as one of the financing institutions that provide many credit facilities to debtors or customers, the Covid-19 Pandemic has a significant impact on debtors' credit agreements. Many debtors are unable to pay off credit installments. From the interviews with Legal Staff and Human Resource Department of BFI Limited Company Ambon Branch Office, Mr. Asri Andreas Laelaem, many debtors have come to BFI to ask for credit relief due to the inability to pay credit installments.

\section{The Effect of Covid-19 Pandemic on Credit Agreements for Debtors}

The Covid-19 Pandemic also impacts not only on business actors but also on banking and financing institutions. The community as debtors has also been greatly affected by this pandemic. In addition to experiencing health problems, another effect experienced is related to a decrease in income, which impacts the implementation of credit agreements with banking institutions and financing institutions. As a community and a credit debtor for BRI Ambon Branch Office, this pandemic outbreak has dramatically affected the food stall business, which is being run by Mrs. Nova in Southwest Maluku Regency, where the food stalls have experienced a drastic decline in income. Meanwhile, on the other hand, she must pay credit installments at the BRI Ambon Branch Office. Due to this pandemic, as a debtor, Mrs. Nova Dahlan could not fulfill her obligation to pay installments according to the specified time. In addition to the Debtor on behalf of Mrs. Nova above, Mr. Joksan 
Manusiwa works as a motorcycle taxi driver. Of course, it impacts the Covid19Pandemic such as not as many passengers as before the pandemic. Meanwhile, he must pay credit installments at the BAF Financing Institution Ambon Branch Office. Finally, in the case of payment of cash credit installments withvehicle ownership documents or Buku Kepemilikan Standar Bermotor (BPKB) guarantees every month, it becomes constrained because it cannot be paid before the due date.

\section{Legal Consequences of Overmachtsin Credit Agreements due to The Covid-19 Pandemic in Ambon City \\ Overmachtor force Majeure is a condition in which the Debtor is unable} to perform his performance to the creditor after the approval is made, which prevents the Debtor from fulfilling their performance, where the Debtor cannot be blamed and does not have to bear the risk and cannot predict at the time of approval created due to different events beyond his control. Such as earthquakes, floods, and accidents. ${ }^{27}$

Almost all contractsor agreements found the phrase "Force Majeure" or "Overmacht". This phrase is a "natural element" of a contract, so this phrase, whether stated or not, is considered to be in a contract or agreement. Articles 1244 and 1245 of the Code of Civil Law have stipulated overmacht as a legal reason that frees the Debtor from the obligation to carry out fulfilment (nakoming) and compensation (schadevergoeding) even though the Debtor has committed an illegal act or onrechtmatig. ${ }^{28}$

The characteristic of theovermacht is divided into two, namely overmacht, which is permanent, and overmacht, which is temporary. On a permanent overmacht that remains a debtor, it cannot perform because of the overmacht. In contrast, on a temporary overmacht, the Debtor will perform again after the overmacht condition ends.

When referring to Law No. 24 the Year 2007 concerning Disaster Management, the Covid-19 pandemic includes non-natural disasters, as stated in Article 1 Paragraph (3). It can be concluded that the Covid-19 Pandemicis an overmacht condition. Some people are considered absolute overmacht, namely those who are no longer able to perform such achievements as Motorbike taxi drivers, victims of layoffs (PHK). However, some of the overmacht are relative, namely those of the micro, small and medium enterprises (MSME) category.

Thus, the Debtor chooses whether a restructuring of credit or financing can be identified with a relativeovermacht or to declare himself an absolute overmacht. However, it should be understood that the overmacht cannot be

\footnotetext{
${ }^{27}$ Annisa Dian Arini, "Pandemi Corona Sebagai Alasan Force Majeur Dalam Suatu Kontrak Bisnis," Supremasi Hukum: Jurnal Kajian Ilmu Hukum 9, no. 1 (2020): 41-56, 41.

${ }^{28}$ Aminah, "Pengaruh PandemiCovid 19 Pada Pelaksanaan Perjanjian", Diponegoro Private Law Review 7, no. 1 (2020): 650-656, 653.
} 
resolved if it is only from both parties (debtors and creditors). Therefore, the Debtor or customer can request a court order.

Due to the law of Overmacht / force majeure / force situation, namely:

a. The Debtor does not need to pay compensation (Article 1244 of The Code of Civil Law)

b. The risk burden does not change, especially in the temporary forcing situation, and

c. Creditors are not entitled to the fulfillment of achievements, but at the same time, are free from their obligations to submit performance contrasts.

Because the Covid-19 Pandemic is categorized as a relative overmacht, the legal consequence of the overmacht in the credit agreement due to the Covid-19 Pandemicin Ambon City has not changed the risk burden in the sense that the Debtor still fulfills theirachievements after the end of Covid-19 Pandemic, or through efforts credit restructuring as determined by the government to be carried out by the bank or financing institution with the Debtor.

\section{Legal Effort to Settle Credit Agreements due to theCovid-19 Pandemic in Ambon City}

The government has made various efforts in addressing the spread of Covid-19 (Corona Virus Disease) even though it seems "slow", including implementing Social Distancing and Physical Distancing as well as LargeScale Social Restrictions (PSBB) through Government Regulation No. 21 the Year 2020. However, the massive impact of Covid-19 has been felt in various lifelines, especially in the economic sector. Likewise, the Financial Services Authority (OJK) issued the Financial Services Authority Regulation No. 11 /POJK.03/2020 Regarding National Economic Stimulus as a Countercyclical Policy Impact of the Spread of Corona Virus Disease 2019 (POJK 11/2020). This policy appears to address the many complaints about the difficulty of access to credit or financing relief to online motorcycle taxis, taxi drivers, micro, small and medium enterprises (MSME/UMKM) entrepreneurs, and temporary workers and workers who are victims of layoffs through credit relaxation.

The main points of POJK (the Financial Services Authority) regulation on the Stimulus Impact of Covid-19 are: ${ }^{29}$

a. This POJK applies to BUK, BUS, UUS, BPR, and BPRS;

b. Banks can implement policies that support economic growth stimuli for debtors affected by the spread of Covid-19, including MSME debtors, by still paying attention to the principle of prudence;

c. Debtors affected by the spread of Covid-19, including MSME debtors,

${ }^{29} \mathrm{Ibid}$. 
are debtors who have difficulty fulfilling obligations to the Bank because the Debtor or Debtor's business is affected by the spread of Covid-19, either directly or indirectly in the economic sector, including tourism, transportation, hospitality, trade, processing, agriculture, and mining.

d. The stimulus policy consists of:

1) Assessment of the quality of credit/financing/other provision of funds is only based on the accuracy of principal and/or interest payments for credit/financing / other provision of funds with a ceiling of up to Rp. 10 billion; and

2) Improvement of credit/financing quality to become smooth after restructuring during the validity period of POJK. This restructuring provision can be applied by the Bank regardless of credit/financing ceiling limits or Debtor type.

e. The way of restructuring credit/financing is carried out as stipulated in the OJK regulations regarding asset quality assessment, among others, by:

1) Lower interest rates;

2) Extension of the period;

3) Reduction of principal arrears;

4) Reduction of interest arrears;

5) Additional credit / financing facilities; and / or

6) Conversion of credit/financing into Temporary Equity Participation.

f. Banks can provide new credit/financing/provision of funds to debtors who have received special treatment under this POJK by determining the quality of credit/financing/other provision of funds carried out separately from the quality of credit/financing / other previous provision of funds.

g. The Bank submits regular reports on the application of this POJK for Supervisory monitoring since the data position at the end of April 2020.

h. This provision is valid from the time of promulgation until 31 March 2021.

After the issuance of POJK 11/2020, debtors felt a little safe because of the "credit relaxation". As understood, credit relaxation means providing concessions related to credit or debt payments. This provision can be seen in Article 2 of the POJK, where banks and financial institutions can implement policies that support economic growth stimulus for debtors affected by the spread of Covid-19, including MSME debtors who are faced with the problem of arrears in credit (non-performing loans).

There are two methods of solving non-performing loans/financing. First, saving problem loans, namely through renegotiation between the bank/finance (creditor) and debtor customers. Second, non-performing loans are settled through legal institutions, such as the PUPN state receivables committee and the Directorate General of State Receivables and Auctions, Judicial Institutions, and arbitration. 
Credit rescue can be done in three forms: rescheduling by making changes to several terms of the credit agreement regarding the repayment schedule or credit term, including changes in the installment amount. Next is reconditioning (re-requirements), which is to change part or all of the agreement's terms without giving additional credit and without converting participation. Finally, restructuring by changing the terms of credit provides additional credit or by converting. Meanwhile, POJK 11/2020 saved credit during the pandemic using a restructuring mechanism.

The restructuring policy still creates problems for bank debtors/financing institutions. Based on searches in several national online media, many customers have complained that banks or financial institutions are still obliged to pay monthly installments. They know the relief in the form of "postponement of installments" and "reduced interest" as conveyed by the President.

There are two discrepancies between the President's statement and POJK $11 / 2020$ in addressing "credit relaxation". First, POJK 11/2020 only states that debtors/customers get relief or relaxation of installments with six options, namely; reduction of interest rates, extension of term, reduction of principal arrears, reduction of interest arrears, additional credit/financing facilities, and/or credit/financing conversion to temporary equity participation so that there were no "postponement" and "interest reduction" options.

Second, Chapter I Article 1 POJK 11/2020 only mentions banking institutions, including non-bank financing companies/institutions such as Multifinance (Leasing). The banks in question are Conventional Commercial Banks, Sharia Commercial Banks, Sharia Business Units, Rural Banks, and Sharia Rural Banks. Meanwhile, the President focuses on assisting informal sector business actors such as motorcycle taxi drivers or taxi drivers who have vehicle loan installments. It can be said that POJK 11/2020 has not accommodated what President Joko Widodo said, namely delaying installments and lowering interest for one year, because micro and small businesses (MSEs) amid the outbreak of Covid-19, their conditions are getting more and more concerned. This condition impacts the national economy, which is getting worse in a situation of uncertainty.

Based on the results of research conducted both at banking institutions such as Bank Mandiri Ambon Branch Office, BCA Ambon Branch Office, Bank Artha Graha Ambon Branch Office, and Leasing Company, namely BFI Limited Company Ambon Branch Office and Credit Debtors at several Banks and financing institutions, it was found that the government's efforts through restructuring which was carried out by banking institutions and financing institutions immensely helped the debtor community who were directly affected by the Covid-19 Pandemic. 
The following is a form of restructuring carried out by banking institutions and financing institutions in Ambon City for debtors affected by the Pandemic of Covid-19:

\begin{tabular}{|c|c|c|c|}
\hline No. & $\begin{array}{l}\text { Name of } \\
\text { Banking } \\
\text { Institution / } \\
\text { Financing } \\
\text { Institution } \\
\end{array}$ & $\begin{array}{l}\text { Forms of Credit } \\
\text { Restructuring for } \\
\text { Debtors Affected by } \\
\text { the Covid-19 } \\
\text { pandemic }\end{array}$ & $\begin{array}{l}\text { Procedure for } \\
\text { Implementing Forms of } \\
\text { Restructuring }\end{array}$ \\
\hline 1. & $\begin{array}{l}\text { Bank Mandiri, } \\
\text { Limited } \\
\text { Company, } \\
\text { Ambon Branch } \\
\text { Office }\end{array}$ & $\begin{array}{l}\text { 1. The Debtor does not } \\
\text { pay interest and } \\
\text { principal for one year. } \\
\text { 2. The Debtor only pays } \\
\text { interest without } \\
\text { principal loan } \\
\text { payments for one } \\
\text { year. } \\
\text { 3. The Debtor pays only } \\
\text { the principal loan } \\
\text { without interest for } \\
\text { one year. }\end{array}$ & $\begin{array}{l}\text { To determine the form of } \\
\text { restructuring to be given to } \\
\text { the Debtor, the Bank will } \\
\text { conduct a field analysis of } \\
\text { the Debtor's conditions } \\
\text { and circumstances. After } \\
\text { further analysis, the next } \\
\text { step is to apply which } \\
\text { form of restructuring. } \\
\text { Usually, the Debtor } \\
\text { directly affected by the } \\
\text { Covid-19 Pandemic will } \\
\text { be prioritized. }\end{array}$ \\
\hline 2. & $\begin{array}{l}\text { Bank BCA, } \\
\text { Limited } \\
\text { Company, } \\
\text { Ambon } \\
\text { Branch } \\
\text { Office. }\end{array}$ & $\begin{array}{l}\text { 1. Extension of Credit } \\
\text { Periods for debtors } \\
\text { affected by the } \\
\text { Pandemic. } \\
\text { 2. The Debtor only } \\
\text { pays interest without } \\
\text { principal loan } \\
\text { payments for one year. } \\
\text { 3. The BankBank will } \\
\text { interest rate cut, so } \\
\text { debtors affected by the } \\
\text { pandemic can pay off } \\
\text { their instalments. }\end{array}$ & $\begin{array}{l}\text { To determine the form of } \\
\text { restructuring that will be } \\
\text { applied to debtors, Bank } \\
\text { BCA will make first } \\
\text { observations } \\
\text { surveillance and analyze to } \\
\text { determine the form of the } \\
\text { restructuring. } \\
\text { Debtors that are prioritized } \\
\text { are debtors directly } \\
\text { affected, such as business } \\
\text { actors in the tourism, } \\
\text { hospitality, travel, } \\
\text { restaurants and restaurants, } \\
\text { and trade industries. } \\
\text { Even if possible, BCA will } \\
\text { provide an extension of the } \\
\text { credit period up to } 10\end{array}$ \\
\hline
\end{tabular}




\begin{tabular}{|c|c|c|c|}
\hline & & & Years. \\
\hline 3. & $\begin{array}{l}\text { Bank Artha } \\
\text { Graha, Limited } \\
\text { Company, } \\
\text { Ambon Branch } \\
\text { Office }\end{array}$ & $\begin{array}{l}\text { 1. Postponement of } \\
\text { principal loan payment } \\
\text { obligations } \\
\text { 2. Lower interest rates }\end{array}$ & $\begin{array}{l}\text { To postpone paying the } \\
\text { principal loan, it will give } \\
\text { debtors a credit of more } \\
\text { than } 5 \text { billion Rupiah. In } \\
\text { contrast, it will be given to } \\
\text { debtors with a loan of less } \\
\text { than } 5 \text { billion Rupiah for a } \\
\text { reduction in interest rates. } \\
\text { Same with Bank Mandiri } \\
\text { and Bank BCA, this } \\
\text { restructuring is prioritized } \\
\text { for debtors who are } \\
\text { directly affected by } \\
\text { Covid-19 Pandemic }\end{array}$ \\
\hline & \begin{tabular}{|l} 
BFI \\
Limited \\
Company \\
Ambon \\
Branch \\
Office
\end{tabular} & $\begin{array}{l}\text { Extension of the credit } \\
\text { period to reduce } \\
\text { amount of installments }\end{array}$ & $\begin{array}{l}\text { As the procedure for } \\
\text { obtaining this } \\
\text { restructuring, the Debtor } \\
\text { must submit it first to BFI } \\
\text { and then be processed to } \\
\text { request approval from the } \\
\text { head office. } \\
\text { Before approval is made, } \\
\text { observations will be made } \\
\text { to determine whether the } \\
\text { Debtor is directly affected } \\
\text { by the pandemic or not. } \\
\text { If the analysis results show } \\
\text { that the Debtor is indeed } \\
\text { affected by the pandemic, a } \\
\text { credit restructuring will be } \\
\text { given. } \\
\text { This credit restructuring is } \\
\text { given to all debtors except } \\
\text { for debtors who are civil } \\
\text { servants because they are } \\
\text { considered not affected by } \\
\text { the Covid - } 19 \text { Pandemic. }\end{array}$ \\
\hline
\end{tabular}

Whereas for debtors affected by the Covid-19 Pandemic, the restructuring policy provides relief to debtors to pay off their credit installments. Based on the results of research on several debtors, it was found 
that there were efforts made by banking institutions and financing institutions to prevent lousy credit from occurring, namely as follows:

\begin{tabular}{|c|c|c|c|}
\hline No. & \begin{tabular}{|l} 
Debtor's \\
Name
\end{tabular} & $\begin{array}{l}\text { The form of } \\
\text { restructuring } \\
\text { was obtained }\end{array}$ & Restructuring Implementation \\
\hline 1. & $\begin{array}{l}\text { Nova } \\
\text { Dahlan } \\
\text { (Food stall } \\
\text { businessw } \\
\text { oman ) }\end{array}$ & $\begin{array}{l}\text { The form of } \\
\text { restructuring } \\
\text { obtained is } \\
\text { interest } \\
\text { payments } \\
\text { without } \\
\text { principal loan } \\
\text { payments for } \\
\text { two years. }\end{array}$ & $\begin{array}{l}\text { The credit taken is Business Credit } \\
\text { through BRI Ambon Branch Office } \\
\text { by submitting a credit request to the } \\
\text { Bank. After that, the Bank makes } \\
\text { observations on the Debtor's business } \\
\text { condition. After being analyzed, Ms. } \\
\text { Nova received credit relief in the form } \\
\text { of a delay in payment principal for } \\
\text { two years. }\end{array}$ \\
\hline 2. & \begin{tabular}{|l} 
JoksanMa \\
nusiwa(M \\
otorbike \\
Taxi \\
Driver / \\
Ojek )
\end{tabular} & $\begin{array}{l}\text { The form of } \\
\text { restructuring } \\
\text { obtained is } \\
\text { interest } \\
\text { payments } \\
\text { without } \\
\text { principal loan } \\
\text { payments for } \\
\text { two years. }\end{array}$ & $\begin{array}{l}\text { Credit taken at the financing } \\
\text { institution BAF Limited Company } \\
\text { Ambon Branch Office is a Cash } \\
\text { Credit guaranteed by BPKB Motor. } \\
\text { Due to this pandemic, the BAF was } \\
\text { only required to pay interest for two } \\
\text { years without paying the principal } \\
\text { loan. The principal will be paid after } \\
\text { two years. }\end{array}$ \\
\hline
\end{tabular}

\section{Conclusions}

The Covid-19 Pandemic is a non-natural disaster. It can be categorized as a relative overmacht, so the result of the comparative overmacht law in the credit agreement due to the Covid-19 Pandemic in Ambon City has not 
changed the risk burden in the sense that the Debtor still fulfillstheir achievements after the outbreaks of Covid-19 Pandemic is over.

Legal efforts that can be taken to settle credit agreements due to the Covid19 Pandemic in Ambon City are through credit restructuring in the form of lowering interest rates, extending the period, reducing principal arrears, reducing interest arrears as determined by the government to be implemented by the bank or financing institutions with debtors.

\section{Reference}

Alessandro Allegra et al. "Immunopathology of SARS-CoV-2 Infection: Immune Cells and Mediators, Prognostic Factors, and ImmuneTherapeutic Implications," International Journal of Molecular Sciences 4, no. 3, 2020: 194-201, DOI: 10.3390/ijms21134782.

Aminah. "PengaruhPandemiCovid 19 PadaPelaksanaanPerjanjian". Diponegoro Private Law Review 7, no. 1, 2020: 650-656.

Arini,Annisa Dian. "Pandemi Corona Sebagai Alasan Force Majeur Dalam Suatu Kontrak Bisnis," Supremasi Hukum: Jurnal Kajian Ilmu Hukum 9, No. 1, 2020: 41-56.

Elfiani. "Akibat Overmacht (Keadaan Memaksa) Dalam Perjanjian Timbal Balik," Al Hurriyah : Jurnal Hukum Islam 13, No. 1, 2018: 65-77, DOI: 10.30983/Alhurriyah.V13I1.582.

Financial Services Authority Regulation No: 11 / POJK.03 / 2020 concerning National Economic Stimulus as a Countercyclical Policy Impact of the Spread of Corona Virus Disease.

Fitri, Wardatul. "Implikasi Yuridis Penetapan Status Bencana Nasional Pandemi Corona Virus Disease 2019 (COVID-19) Terhadap Perbuatan Hukum Keperdataan," Supremasi Hukum: Jurnal Kajian Ilmu Hukum 9, no. 1, 2020: 76-93.

Hanim, Lathifah., Noorman,MS. "Penyelesaian Perjanjian Kredit Bank Sebagai Akibat Force Majeure Karena Gempa Di Yogyakarta," Jurnal Pembaharuan Hukum 3, no. 2, 2016: 161-171,DOI: 10.26532/jph.v3i2.1406.

Hapsari, Dwi. "Kontrak Dalam Kitab Undang - Undang Hukum Perdata Dan Hukum Islam (Suatu Kajian Dalam Perspektif Asas - Asas Hukum)," Repertorium 1, no. 1, 2014: 83-94.

Hartono, C. F. G. Sunaryati. Mentjari Bentuk dan Sistim Hukum Perdjanjian Nasional Kita. Bandung: Alumni, 1969.

Hernawan,Ari. "Keseimbangan Hak Dan Kewajiban Pekerja Dan Pengusaha

Dalam Mogok Kerja," Mimbar Hukum-Fakultas Hukum Universitas Gadjah Mada 24, no. 3, 2012: 418-30.

Hetharie, Yosia. "Default in Sea Transportation Agreement," Law Research Review Quarterly 6, no. 2, 2020: 181-184,

DOI:10.15294/lrrq.v6i2.37900. 
Hetharie, Yosia. "Perjanjian Nominee Sebagai Sarana Penguasaan Hak Milik Atas Tanah Oleh Warga Negara Asing (WNA) Menurut Kitab UndangUndang Hukum Perdata," SASI 25, no. 1, 2019: 27-36,DOI: 10.47268/sasi.v25i1.147.

Irianto, Sulistyowati. Legal Practice: Sociolegal Perspective. Jakarta: Obor Foundation, 2009.

Irianto, Sulistyowati. Praktik Hukum: Perspektif Sosiolegal. Jakarta: Yayasan Obor, 2009.

Isradjuningtias, Agri Chairunisa. "Force Majeure (Overmacht) Dalam Hukum Kontrak (Perjanjian) Indonesia," Veritas et Justitia 1, no. 1, 2015: 136158, DOI: $10.25123 /$ vej.1420.

Khairandy, Ridwan. "Landasan Filosofis Kekuatan Mengikatnya Kontrak," Jurnal Hukum Ius Quia Iustum 18, 2011: 36-55.

Law Number 10 the Year 1998 concerning Banking.

Law Number 24 the Year 2007 concerning Disaster Management.

Noor, Muhammad. "Penerapan Prinsip-Prinsip Hukum Perikatan Dalam Pembuatan Kontrak.” Mazahib 14, no. 1, 2015: 89-96.

Nuraini, Hanifah.,Dauri., Andreas,Ricco. "Paradigma Interpretif Konsep

Penyalahgunaan Keadaan (Misbruik Van Omstandigheden) pada Perjanjian Kredit Perbankan," Refleksi Hukum: Jurnal Ilmu Hukum 4, no. 2, 2020: 259-80, DOI: 10.24246/jrh.2020.v4.i2.p259-280.

Panggabean, Henry Pandapotan. Peranan Mahkamah Agung Melalui Putusan-Putusan Hukum Perikatan. Bandung: Alumni, 2008.

Panggabean, Henry Pandapotan. The Role of the Supreme Court through Obligation Law Bond Decisions. Bandung: Alumni, 2008.

Pesulima, Theresia Louize. Hetharie, Yosia "Legal Protection of Work Safety for Workers Health Due to the Covid-19 Pandemic", SASI Journal 26, no. 2, 2020: 281 .

Presidential Decree Number 12 the Year 2020 concerning the Designation of Non-Natural Disasters for the Spread of Corona Virus Disease 2019 (Covid-19) As a National Disaster.

Rasuh, Daryl John. "Kajian Hukum Keadaan Memaksa (Force Majeure) Menurut Pasal 1244 Dan Pasal 1245 Kitab Undang-Undang Hukum Perdata," Lex Privatum 4, no. 2, 2016: 173-180.

Rothan, HA Byrareddy SN. "The Epidemiology and Pathogenesis of Coronavirus Disease (COVID-19) Outbreak".Journal Autoimmun 109, 2020: 102433, DOI: 10.1016/j.jaut.2020.102433.

Siombo, Marhaeni Ria., Adi, Waluyo., Ariananto, Emmanuel. "Impilkasi Keppres No. 12 Tahun 2020 Pada Perusahaan Pembiayaan," Refleksi Hukum: Jurnal Ilmu Hukum 5, no. 1, 2020: 85-104, 85, DOI: 10.24246/jrh.2020.v5.i1.p85-104.

Sirait,Manaon Damianus., Kosasih, Johannes Ibrahim., Arini, Desak Gde Dwi. "Asas Itikad Baik Dalam Perjanjian Sewa-Menyewa Rumah 
Kantor," Jurnal Analogi Hukum 2, no. 2, 2020: 221-227, DOI: 10.22225/ah.2.2.1934.221-227.

Sunandar, Taryana. Prinsip Prinsip Unidroit Sebagai Sumber Hukum Kontrak Dan Penyelesaian Sengketa. Jakarta: Sinar Grafika, 2004.

Sunandar, Taryana. Unidroit Principles as a Legal Source of Contracts and Settlements Dispute. Jakarta: Sinar Grafika, 2004.

Sutiyoso,Bambang. "Penafsiran Kontrak Menurut Kitab Undang-Undang Hukum Perdata dan Maknanya Bagi Para Pihak Yang Bersangkutan," Jurnal Hukum Quia Iustum 20, no. 2, 2013: 207-233, DOI: 10.20885/iustum.vol20.iss2.art3.

The 1945 Constitution of the Republic of Indonesia. The Code of Civil Law. 
